\title{
"I am Satan!" black metal, Islam and blasphemy in Turkey and Saudi Arabia
}

\author{
Jonas Otterbeck $^{1}$ (D) Douglas Mattsson ${ }^{1}$. \\ Orlando Pastene ${ }^{1}$
}

\begin{abstract}
During the last decade, black metal bands have recorded anti-Islamic music in Turkey and Saudi Arabia. Black metal is renowned for being antiauthoritarian and especially against organized religion. As such, black metal music is a strong expression of protest against, and repudiation of, society, manifesting social pressure, and contrasting with the discursively normal. Using the results from two case studies - one on Turkey, the other on Saudi Arabia this article argues that black metal expressions in the two countries must be perceived as subcultural expressions to the Islamic ideology of the respective states as well as the dominant culture in society at large. Further, we argue that a multimodal, semiotic reading of the bands' musical expressions opens up a field for Islamic studies seldom approached before.
\end{abstract}

Keywords Black metal Islam · Turkey· Saudia Arabia · Blasphemy · Islamic studies

TO THEM, THE STRAIGHT PATH [al-siratu l-mustaqimu], ${ }^{1}$

I AM SATAN [al-shaytan],

AND IN TYRANNY [al-jabrut] RESIDES MY STRENGTH

\footnotetext{
${ }^{1}$ Al-Namrood is very cautious about spreading their lyrics in Arabic. Therefore, we will only give the keywords we are analyzing in transliterated Arabic.
}

Jonas Otterbeck

Jonas.Otterbeck@ctr.lu.se

Douglas Mattsson

douglas.gideon.mattsson@gmail.com

Orlando Pastene

orlando.pastene@gmail.com 
AND TO ME BELONGS THE CLEAR VICTORY ${ }^{2}$ [al-nasrin al-mubinin]. (Excerpt from "Jabaroot Al Shar"/jabrut al-sharr (The tyranny of the evil) ${ }^{3}$ by alNamrood, translation by Otterbeck)

(1) Surely We have given you a clear victory (fathan mubinan).

(2) That Allah may forgive for you what preceded of your sin and what will follow and complete His favor upon you and guide you to a straight path [siratan mustaqiman].

(3) And that Allah might help you with a mighty victory/help [nasran azizan].

(The Qur'an 48:1-3, translation by (1) Shakir (2) Sahih International (3) both, mixed)

The second quote is a famous passage from the Qur'an, suratu l-fath (The sura of victory), where Allah is considered to proclaim his support for Muhammad. The first - quoted in uppercase to mediate the loud growl - is from "Jabaroot Al Shar" (The tyranny of the evil), a song from Saudi Arabian black metal band alNamrood's first CD, Astfhl Al Thar (istafhala al-tha'r: The vengeance has intensified) ( 2009). The allusion to Qur'anic language is explicit as al-Namrood is using words like nasr and mubin as well as al-siratu l-mustaqim. Further, al-jabrut is a fairly common Qur'anic word. According to traditional exegesis, Allah is the one speaking in first person in the Qur'an, referring to himself as either I, We, or Allah. ${ }^{4}$ By using a Qur'anic-influenced language and growling "I am Satan”, making Satan the addresser, the blasphemous intent of the song is obvious. ${ }^{5}$ If the song caught the attention of Saudi authorities, the lyrics would likely be considered sabb al-qur'an (slandering of the Qur'an) or a proof of ridda (apostasy) by the musicians, the punishment for both being - in a worst-case scenario - death, if those uttering the words do not repent. ${ }^{6}$

This article is about a recent subcultural phenomenon in Turkey and Saudi Arabia the emergence of consciously blasphemous black metal targeting Islam. The phenomenon has also surfaced in other countries, but is still marginal. A very early example is

\footnotetext{
${ }^{2}$ Nasr is a tricky word that may mean both help and victory. Here, it is most likely victory that is meant, while in the passage of the Quran below, most translations render nasr as help.

${ }^{3}$ Al-Namrood often uses an odd transliteration of Arabic for titles so we give both the band's version and a regular transliteration (if warranted) to enable for those who understand some Arabic to see which words are used. Many of the band's songs, including this one, can be heard on: al-Namrood, web.

${ }^{4}$ To be fair, Allah is also referred to as he, as in the quoted sura, implying that Allah is being spoken about in third person singular, often in the combination "Allah...he...". Exegetes in Islam interpret this as Allah speaking about himself.

${ }^{5}$ A similar rhetoric positioning, i.e. addressing the listener from the position of Satan, can be found on Turkish black metal band Zifir's song "Mina” ( 2017).

${ }^{6}$ We have discussed the ethics of our research at length. We are somewhat surprised by the risks taken by both Turkish and Saudi bands. While words can be hidden within the music, images are hard to conceal; printing lyrics, making explicit covers, having a presence online, performing in public in societies that have legal tools to censor artistic expressions, might give rise to severe lawsuits against the bands. As we are not disclosing anything about any of the individual members of the bands, and as all images and lyrics used are easily available on Internet we deem it possible to write about the phenomenon.
} 
Lebanese Ayat's song "Ilahiya Khinzir" (My God is a Swine) (2008) that is obtrusively harsh. The article raises the question how Islamic studies may approach this phenomenon and include it in its field of study. It is based on two unique case studies - one being the black metal scene in Istanbul (Mattsson 2015, 2016) and the other, the Saudi black metal band al-Namrood (Pastene 2016). ${ }^{7}$

Black metal is a highly multimodal expression and both the lyrics and the brutality of the musical and visual expressions are central to understanding the genre's metanarrative, which reeks of anti-establishment and anti-authoritarian rhetoric, part of which is a provocative resistance to and disdain of religion. The bands very often use consciously blasphemous verbal expressions and images, putting blasphemy at the heart of the black metal metanarrative. Other typical traits are the visual celebration of death and suffering expressed on stage, on covers and in video clips, the usage of corpse paint (a style introduced by Danish artist King Diamond), and a preference for pitch black and shining white creating drastic contrasts. Black metal artists' visual and lyrical fixation with death is only superseded by the religions they criticize.

Growling (the most common vocal technique of the genre) makes it quite hard to grasp lyrics at live shows; without printed lyrics, it may even be difficult when listening to recordings. As with most lyrics, they are meant to be experienced together with the music. Still, lyrics are not unimportant. They often express - in impressionistic, short phrases - the metanarrative of black metal. However, the listener is not required to have esoteric pre-knowledge of black metal metaphors or a degree in literature to get the message. The following lines, growled in English, are from a Turkish black metal band:

SPREADING VX GAS OVER FUCKING KAABA

FINALLY COMING OF RADIATIONAL WHIRLWINDS

SPREADING VX GAS OVER FUCKING KAABA

COLLAPSING OF FUCKING MUSLIM EMPIRE

("Spreading VX Gas over Kaaba" from Sarinvomit's album Baphopanzers of the

Demoniacal Brigade ( 2015) Seven Gates Of Hell Records. The song can be heard on Sarinvomit, web)

We will return to and analyze these lyrics in detail below; here it suffices to note the hostile tone. As mentioned, consciously blasphemous black metal in both Turkey and Saudi Arabia is a fairly new phenomenon so, after an introduction to black metal in general, the article discusses the emergence of black metal in the two countries; it then presents an analysis of the music (lyrics, images, sounds) of the bands, and finally discusses the importance of the phenomenon in relation to studies of Islam.

\footnotetext{
${ }_{7}^{7}$ Mattsson conducted a month of fieldwork in Istanbul 2014 and also analyzed recordings and covers. Pastene interviewed al-Namrood by email in 2015 as well as analyzing the group's recordings, sleeves, and videos. The band members consistently claim that they live in Saudi Arabia, and from their answers in interviews it is likely that they do. However, there have been cases of hoaxes before regarding cultural expressions claimed to come from the Middle East. But as of now, we believe the band really do operate from within Saudi Arabia. This view is supported by journalist O. Crowcroft (2017: 178) who claims to have verified that al-Namrood really is a Saudi band.
} 


\section{Black metal}

Black metal is a subgenre under the wide "metal" canopy, and generally considered to be one of the most vicious offsprings of metal. It is frequently associated with the violence, murders, and church arsons that occurred when black metal became established in Norway in the beginning of 1990s (often addressed as the second wave of black metal) (Moynihan and Søderlind 1998/2003). There is no consensus about which band should be credited for introducing black metal, but most researchers and fans mention Venom's second album Black Metal from 1982 as one of the cornerstones of the genre. Other early bands of the first wave of black metal include Mercyful Fate, Bathory, and Hellhammer and many later black metal bands namedrop these groups as a source of inspiration (Patterson 2013). Even though the early bands had no homogeneous style, they were faster, darker, and more unpolished than other metal bands at the time. Lyrics often consciously blasphemed against Christianity. During the thirtyfive years of the genre, it has developed a recognizable style, but also continuously incorporates style elements from other genres and likewise exports its signatures, blurring boundaries between what may and may not be called black metal.

To qualify as black metal, a band needs, at least, some songs with a particular kind of interlacement of all instruments, including the voice, in a soundscape where the intense velocity and ferocity combined with musical precision create an overall impression hard to describe in words. Often melodies may be quite slow even though the instruments creating them are played at a high tempo, for example guitarist frequently use tremolo picking. Listeners without prior experience are likely to get lost (Where does a bar or a riff start? Where is the structure to hold on to?), not knowing how to experience the music competently. Not least, blast-beat drumming makes it more difficult to use prior rock-listening skills (there is no backbeat; rather one must listen to the cymbals). More experienced listeners find that the structure and the repetitive elements in guitar and bass riffs conjure up associations with both metal at large (like trash and death), and punk.

But black metal has developed in different directions; for years such genres as symphonic black metal and Folk black metal have existed. Black metal can also be slow and fundamentally doomsday-like in contrast to our description of the core element above. However, this development is generally what happens to music genres gaining some popularity. We politely leave the quibbling over boundaries to artists and fans. When only discussing the music, "extreme metal" - a wider concept covering different kinds of extreme metal like death and black metal (Kahn-Harris 2007) - might be more appropriate, but since this article concentrates on the element of blasphemy, which is at the heart of black metal, we have chosen to use the term black metal throughout.

From the very beginning, black metal has been associated with occultism and Satanism. Some artists, but far from all, claim to be Satanist, like King Diamond in Mercyful Fate. What is shared is a radical anti-establishment ethos most often directed towards Christianity and Christians. These lines from Darkthrone's "Unholy Black Metal" (from Under a Funeral Moon, 1993, Peaceville Records) may serve as an example:

WHEN JEHOVAH'S HORDES ARE SLAUGHTERED

WHEN DISCIPLES TWELVE ARE DEAD

WHEN BEHETH OF EASTER LANDS

AND RAPED AND RAPED AGAIN 


\section{WHEN THE WHORE OF BABYLON RIDES \\ WHEN FURY TURNS TO HATE \\ WHEN ALL SONS OF SATAN \\ SODOMIZE THE LAMBS OF CHRIST}

Typically, the lyrics do not settle for refuting religion; they call for the violent extermination of it, its symbolic places, and its adherents. Images on covers (such as frequent depictions of Satan), symbols (like the sigil of Baphomet), symbolic acts (Behemoth's vocalist tearing out pages of a Bible), and images on stage and in videos (like Gorgoroth's stage setting of crucified people) beg to be interpreted as consciously blasphemous. At times, aural references are also made to religion, and to blasphemy. For example, Norwegian Gorgoroth's album Antichrist (1996) is introduced by church bells and many bands make frequent use of the tritone interval thought of as the Devil's interval since medieval times (Arnold 1983). Today, black metal is a global metal style with bands also in the so-called Middle East, and the target of spite now includes Islam and Muslims. The latter is a very new phenomenon. In 2007, Keith Kahn-Harris claimed (Kahn-Harris 2007: 48) that "Islam (...) has never been the object of aesthetic transgression." Since, a few scholars have noted anti-Islamic lyrics and imagery in black metal outside of the Middle East, and it seems to be on the rise (Venkatesh et al. 2016; Faxneld 2017).

Blasphemy merits a few comments before we proceed. Charges of blasphemy are relational and, as such, have parallels with censorship. In history, blasphemy charges have been efficient in silencing people, especially when seeking grounds for punishing or persecuting heterodox or minority religious movements (Lawton 1993; Nash 2007). However, in our cases, no one has charged the bands discussed with blasphemy, even though state laws (the Turkish case) or political, judicial praxis (the Saudi case) probably could be used. Rather, when we write blasphemy, we are referring to the black metal bands' ambitions to use Islamic semiotic resources (i.e. doctrines, key characters, keywords, and symbols) in ways that provoke and insult.

\section{Black metal in Turkey and Saudi Arabia}

While both metal and black metal have been studied thoroughly, only a small number of scholars have written about metal in the Middle East, with few comments on black metal. A pioneering work was Mark LeVine's Heavy Metal Islam (2008). ${ }^{8}$ However, neither the book nor his later articles (for examples 2009, 2011) address black metal. In his graduate thesis, The Devil's Prayers: Metal Music in Iran (2014), Jeremy Prindle explores metal music in Iran. But like LeVine, he does not focus on black metal. The most ambitious research done as of now is the PhD thesis of Pierre Hecker, Turkish Metal: Music, Meaning and Morality in a Muslim Society (2012). It features a chapter about the Turkish black metal scene. In it, Hecker reports anecdotally on a change in Turkish black metal when artists started to use Islamic symbols, trying to provoke by inverting the Islamic crescent, among other things. Hecker had no opportunity to

\footnotetext{
${ }^{8}$ The book was accompanied by a webpage (heavymetalislam.net), a CD compilation Flowers in the Desert (2009) and a film Before the Spring, After the Fall (2013).
} 
pursue the phenomenon further and called for more research (Hecker 2012: 137ff). A very recent book, Rock in a Hard Place: Music and Mayhem in the Middle East (2017), by journalist Orlando Crowcroft contributes fine observations and interviews with metalheads in Iran and in a number of Arab countries, among them Saudi Arabia. It includes several passages on extreme metal, including an interview with Mephisto from al-Namrood. Crowcroft also mentions a few anti-religious metal bands from other countries and points out that such bands are rare.

\section{Turkey}

Founded in 1988 in Ankara, Witchtrap is likely the first Turkish black metal band. Pagan, Ebonsight, and Infected are also among the first. However, the first black metal album, Witching Black by Witchtrap, was not released until 1997. Most bands can be found in the urban centers of Istanbul, Ankara, Izmir, Bursa, and Eskișehir. Even if the scene is primarily underground, some bands have become fairly successful. For example, Episode 13, Black Omen, and Moribound Oblivion have toured in Germany (Hecker 2012: 134ff). In recent years, Hellsodomy, Engulfed, and Sarinvomit have played at festivals and toured in Europe.

In the early years of the twenty-first century, the Turkish metal scene was hampered by a societal moral panic about Satanism, metal, and criminality, fueled by the media and supported by the government. Simultaneously, the AKP came into power for the first time and has kept it since. Similar demonization of metal music occurred roughly at the same time in Morocco, Egypt, Israel, Lebanon, Iran, and Pakistan (LeVine 2008) and has been reoccurring since (Crowcroft 2017). The narrative about the moral panic is still very much alive and threatening to aspiring metal artists, according to Mattsson's fieldwork (2015).

The black metal music we are analyzing saw first light in the AKP's Turkey and will have to be understood in a context of resistance against what is perceived as an Islamist government by the studied bands. It is no coincidence that blasphemous black metal emerged under these political circumstances. As of now, these bands and their music have not been noticed in mainstream Turkish media nor by the judicial system.

It must be stressed that even though Turkey has no clear-cut blasphemy law, article 216, "Provoking people to be rancorous and hostile", under the fifth section, "Offenses Against Public Peace", of the Turkish law regulates hate crimes, blasphemy, and religious insults. The last paragraph of article 216 states: "Any person who openly disrespects the religious belief of a group is punished with imprisonment from six months to one year if such act causes potential risk for public peace" (Legislation online, web). Articles 213, 215, 217 may also be used in a case regarding blasphemy. Thus, blasphemy is not only a judgement from the perspective of religious officials, or a moral position; it is a legal category.

\section{Saudi Arabia}

Saudi-Arabia was once a culturally closed society, but due to international travel and migration, and new transnational cultural spheres accessible through digital media and the Internet, Saudis are (or can be if they so choose) exposed to much the same cultural products as the rest of the world, including the possibility of seeking out subcultural 
music. Freedomhouse.com (web) estimates that $70 \%$ of Saudis had Internet access in 2016, a fairly wide distribution considering that public Internet was made available in 1999 (Ramsey and Fatani 2016). Even though the Saudi state - especially its Islamic scholars - has the ambition of enforcing censorship on ideologies and cultural expressions not to its likening, ${ }^{9}$ many Saudis easily bypass the massive censorship of the Internet (Otterbeck 2012; Crowcroft 2017).

We have not found reliable figures on the number of active metal bands in Saudi Arabia. The website "Saudi Metal", set up by a Saudi metal musician in 2002 (Crowcroft 2017: 165) but closed down in 2011, listed sixty bands in 2010, some of which were only very temporary constellations. Encyclopaedia Metallum (web) lists twelve active bands in 2017. The oldest one, Forgotten, supposedly formed in 1996, has only one song listed. The majority of the bands were formed from 2005.

There are no record companies in Saudi Arabia releasing metal music. Instead, the bands either just upload their music or find record companies in Europe or North America prepared to produce and distribute it. Public concerts are extremely rare and not legal if not granted special permission. Crowcroft (2017) mentions a handful of gigs, most of them in private houses. Because of this, there is no public metal scene or metal clubs in the country. Rather, during his travels in Saudi, Crowcroft met with isolated islands of metalheads in different cities. Nonetheless, there are a few bands classified as black metal in Saudi Arabia, al-Namrood being the most well-known. Encyclopaedia Metallum (web) also lists Immortal Seth and Mephisophilus as black metal. One member of Mephisophilus is also part of alNamrood.

Saudi mainstream media have mostly ignored the metal bands, but in an unusual article from 2008 in state-controlled daily al-Hayat (web), three metal bands - Wasted Land, Immortal Pain and Grieving Age - were given the opportunity to explain their music. The article was sympathetic and gave the impression that the members were "decent Saudis with an odd hobby" (Otterbeck 2012: 346). As far as we know, no attention has been paid to Saudi black metal, and certainly not to its lyrics.

Formed in 2007, al-Namrood has released albums since 2008 through Canadian Shaytan Productions. The band's name alludes to a character in Islamic Qur'an exegesis (tafsir) representing God-denying, evil-minded, mundane political powers. ${ }^{10}$ Playing in al-Namrood is kept secret, even from family and friends. The band members are careful to be completely anonymous as the risk of legal suits against them is overwhelming. Challenging religious symbols or religious authority can lead to severe punishments including the death sentence (see Human Rights First, web, p. 52-53). Because of this, al-Namrood has never risked performing live.

To present and analyze our two cases, we have divided the material into three parts: Lyrics and titles; Images; Music and sounds, each section dealing with an aspect of the multimodal expression.

\footnotetext{
${ }^{9}$ Typically, in January 2017, grand mufti 'Abd al-'Aziz Al al-Sheikh lashed out against vocal concerts and cinemas (both banned at the time) claiming that they are likely to "open the doors to evil" according to several reports (Sharman 2017). Since 2018, cinemas are allowed again in Saudi Arabia and companies are preparing to explore the market according to Arab News (web) 1 March.

${ }^{10}$ Al-Nimrud (the transliterated version of the name) is never mentioned by name in the Qur'an but Muslim exegetes agree that Sura 2:258 makes reference to him and that he is the same person as Nimrod of the Bible. For example, see the two classical tafsirs Tanwir al-Miqbas min tafsir and Tafsir al-jalalayn.
} 


\section{Lyrics and titles}

While singing/growling (or hissing or screaming) in black metal clearly contributes to rhythm and melody, words and topics of songs are still an important aspect, as attested by one of Mattsson's informants:

The lyrics are extremely important of course. No matter how good a band sounds, without satanic concepts dealing around themes like destruction, evil, desecration, fanaticism, and devil worship, it will never be a real black metal band in my eyes. Black metal has become more than "just music". One has to provide more than just some riffs and shrieks to be considered a black metal band.

Similar attitudes were stated by other bands, in both countries. ${ }^{11}$ We argue that black metal lyrics must be understood in relation to the genre's metanarrative rather than seeing them as only confined in one song's structure. Still, there are differences in style and approach. While the Turkish bands all sing in English and have shared lyrics with Mattsson and published them in CD-folders or online, Saudi al-Namrood did not share lyrics with Pastene. However, lyrics to al-Namrood's first album circulate on the Internet. The lyrics were originally posted by the band - since removed - but they keep appearing in different places, and lyrics to some newer songs can also be found. However, al-Namrood was kind enough to discuss the overall content of the lyrics with Pastene.

One of the most blasphemous songs to date, produced by the Turkish black metal scene is the initially quoted 2015 song "Spreading VX Gas over Kaaba" by Sarinvomit. In that sense, it is atypical. Still, in its explicitness it is a good example of how far black metal bands may go in Turkey. Lyrics are reproduced as given.

INFINITE AEON BEGAN FOR HELLISH NUCLEAR DOMINANCE PANDEMONIUM ORDERED TO DEVASTATE THE HOLINESS GOETIC DEMONS GATHERED, TUBES OF VX GAS WERE FILLED DURING THE CIRCUMAMBULATION KAABA WAS ENCIRCLED

PLEASURES OF MASSACRE, ESCAPE OF WORSHIPPERS

SHAMEFUL RELIGIOUS SUPPLICATION

DROWNED IN THEIR VOMIT WHILE THEY'RE PRAYING

PARAMOUNT VIEWS OF DEPRAVATION

ISLAMIC SCRIPTURES WERE TOTALLY DESTROYED

BY THE SACRILEGIOUS ABHORRENCE

EJACULATION OF GOATLORD WHO STANDS ON DEAD PROPHETS

HADJIS ARE AGONIZING UNDER THE RADIOACTIVE MASS

SUFFERING GABRIEL ARE SUCKING IMPURIFIED BLOOD

OF THE DEVIL-STONERS IN MINA

EMBLAZONED GOATS ARE INSEMINATING THEIR WIFES

\footnotetext{
${ }^{11}$ The importance of lyrics is generally acknowledged by black metal bands, see for example Bossius 2003, 2006. 
WITH SEMEN MIXED WITH VX GAS

GENOCIDE WEAPONS CREATED MIASMATIC BLACK SKY

END OF FUCKING SANCTIFIED LIVES

\title{
TEMPESTUOUS LETHAL GAS FOR THE VICTORY OF SLAUGHTER RITES \\ PHENOMENAL DEVASTATION WAR AGAINST THE HUMAN KIND
}

CELEBRATION OF CHEMICAL ARMAMENT AGAINST THE DEVOTEES

BEFOULED DIVINE BODIES EXPLODED AND SPILLED OUT AROUND THOSE WHO FLED TO SHELTERS WERE IMPALED ON POLES IN HEAT

SPREADING VX GAS OVER KAABA, LUST OF MASS POISONING

\author{
SPREADING VX GAS OVER FUCKING KAABA \\ FINALLY COMING OF RADIATIONAL WHIRLWINDS \\ SPREADING VX GAS OVER FUCKING KAABA \\ COLLAPSING OF FUCKING MUSLIM EMPIRE
}

(Spreading VX Gas over Kaaba" from Sarinvomit's album Baphopanzers of the Demoniacal Brigade ( 2015) Seven Gates Of Hell Records)

The lyrics paint a vivid, horrific image of armies of demons attacking the pilgrims during hajj, the pilgrimage to Mecca, raping and slaughtering them. Such explicit, apocalyptic violence and demon-infested visions are fairly common in black metal. But making Islam the specific target is not. The lyrics make frequent references to the pilgrimage: the circumambulation of Ka'ba; "hadjis" (a pilgrim performs hajj and becomes a hajj [masc.] or hajja [fem.] when rituals are over); "devil-stoners in Mina" refers to the stoning of the Devil commemorating Ibrahim's; Hajar's and Ismael's rejection of Shaytan. The mentioning of the archangel Gabriel, prayer, prophets, and worshipers can easily be associated with the hajj. In an almost programmatic declaration, Sarinvomit proclaims what happens a "sacrilegious abhorrence". The message is overtly clear: Death to Islam.

As mentioned, few lyrics are as explicit as this. More often than not the target is religion in general. In interviews with Mattsson, band members have explained that "being" black metal includes hating religion, not only Islam. However, the development has been that hatred for religion first targeted Christianity, as this was the norm in black metal, while the recent trend of attacking Islam is explained in two ways: as a matter of authenticity and a matter of politics.

Because it is our originality I mean, if we used inverted crosses and... churches being burned in our covers, it would mean nothing in this country. $[\ldots]$ if you put [on] an inverted cross in Turkey and you are walking around the street, they would think that you are Christian, not anti-Christian, so it's just meaningless. And since we are from here, since we are against... we are provocative against the traditions of this country and this society. So it is very normal, actually, to me, to use traditional symbols of this country and the religion of this country. 
As expressed in the interview above, if you are Turkish, born to a Muslim family, living in Turkey, criticizing Christianity just becomes a pose; to be true to the ethos of black metal, Islam will have to be targeted. Further, in secular Turkish logic, it is common to claim that the AKP is Islamizing the country and many strongly dislike AKP politics. Even though the bands explicitly claim to be a-political (a common position amongst extreme metal bands, Kahn-Harris 2007: 154), we argue that black metal provides a vehicle for subcultural repudiation of the dominant sector of society, not least the Islamic ideology of the AKP and, in the Turkish context, this becomes political, albeit without offering clear alternatives or political programs.

The lyrics of Saudi-Arabian al-Namrood are inspired by both Islamic and preIslamic history and poetry; the band has, for example, name-dropped the renowned tenth century Arab poet Abu at-Tayyib al-Mutanabbi (d. 965) (see Blachére and Pattel 2012) as an influence (Filhakikat, web). Pastene asked the band if lyrics also deal with present times, to which the members replied that they compare "the ignorance age [i.e. pre-Islamic days] with events nowadays happening in Saudi, like slavery and religious autocracy". They further write about the corruption of the Islamic clergy, the exploitation of religions, and hypocrisy in religion. As with the Turkish bands, a strong discontent with politics, combined with a deep hatred for Islam, motivates and informs the music of al-Namrood. The band members comment in an email why they have chosen an anti-religious message in their music:

We hate religion and anything connected to it; you see the reason we hate it is not because we are philosophers who believe in evolution or other crap. We hate it because we're severely abused by the Islamic people and their regime; since childhood they were trying to intoxicate our brains with their hypocritical religious bullshit.

The lyrics of al-Namrood quoted initially is quite explicit. The song, "Jabaroot Al Shar", continues:

OH MANKIND (ye insan!)! NO RECONCILIATION (sulh) NOR PEACE (salam) BETWEEN US.

OH SOLDIERS OF EVIL!

COME TO FIGHT!

SPREAD PANIC IN THE LIVES OF THE SLAVES ('abid, plural of 'abd with the obvious connotation: the servants/slaves of God)

TOLL THE BELLS!

MUSICAL INSTRUMENTS AND PROBLEMS!

SCREAMING JINNS BETWEEN SNAKES AND CROWS!

OH UNFORTUNATE, ALL ALONE!

OH MANKIND!

YOU ARE DEAD RIGHT AWAY!

THE REVENGE OF THE TAGHUT! (taghut may be translated as the idol, the false God, the Seducer, or the Tempter, all words associated with the Devil) NOW! $!^{12}$

${ }^{12}$ Translation by Otterbeck. 
While lyrics and titles often are violent and gruesome in Turkish black metal, the Saudi band is more inclined to eschatological and historical lyrics, while not leaving violence out, of course. The lyrics are likely to be as provocative; proclaiming God to be the enemy is a statement not often heard from within Saudi Arabia. The frequent use of Qur'anic terminology and imagery is stressed by the fact that al-Namrood's growling is in Arabic, not English. The Turkish bands use Islamic signal words as semiotic resources to clearly mark their deprecation of all things Islamic. By twisting the meaning of Arabic Islamic vocabulary, al-Namrood's intention is clearly blasphemous, not least in light of the Saudi political context.

As with the Turkish case we have chosen to highlight lyrics that are intended to be as blasphemous as possible to emphasize that the phenomenon exists. Other lyrics may be ominous and dark without explicit references to Islam, for example the song "Sihr aswad" (Black Magic) from the same album:

\section{IN THE DUST OF THE EARTH! \\ LIES BLACK MAGIC, DREADFUL! \\ EVIL HAS BECOME DOMINANT! \\ THE TIME IS OUT! \\ WILL YOU COME OUT? \\ WILL YOU APPEAR? \\ I WONDER! \\ IT'S A REVOLUTION! ${ }^{13}$}

In a specifically Saudi logic, black magic and witchcraft are targeted by the Wahhabi clergy as particularly vile and to be eradicated. To celebrate black magic is in itself an attack on the clergy's vision of society (Doumato 2000: 148). While the Turkish bands also rage against other faiths, particularly Christianity, as far as we know this is not the case with al-Namrood. However, it is difficult even for experienced listeners to grasp the lyrics without the print version because of the growling. In this way, bands may conceal the specifics of their harsh messages and rely on the metanarrative of black metal - fans will know what texts are about from titles like: "Fornicated Messiah in the Pandemonium" (Impuration), "Zero Tolerance for Believers" (Persecutory), "Eternal Agonizer" (Horrocious), or "Estorat taghoot (A Legend of Tyranny)" and "Atba'a alNamrood" (Followers of al-Namrood), both by al-Namrood. Of course, not all titles are as explicit as these. But when it comes to images in video clips and on album covers it is another story.

\section{Images: band logos, covers, videos, concerts and posters}

Turkish bands like Persecutory (Fig. 1), Impuration, Godslaying Hellblast, and Saudi al-Namrood (Fig. 2) have all chosen band logos visibly signaling an affinity to the black metal genre. ${ }^{14}$

\footnotetext{
13 Translation by Otterbeck.

${ }^{14}$ Examples of other black metal band logos may be found by performing an image search using "black metal logo" as keywords.
} 


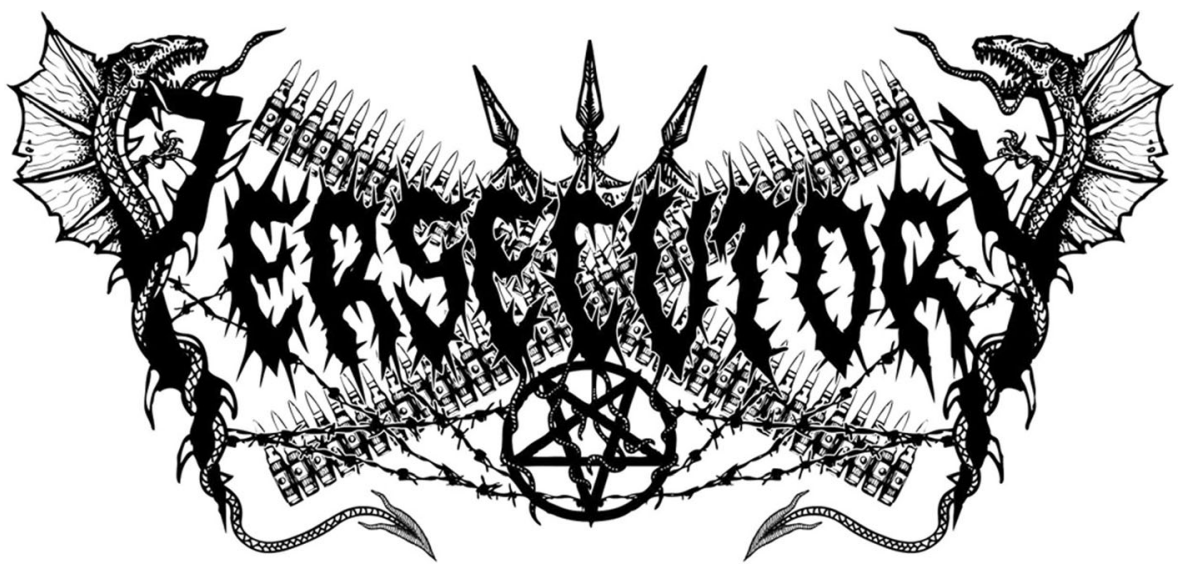

Fig. 1 Persecutory logo. Two serpentine dragons frame the logo which also features a centered pentagram and two crossed ammunition belts, signaling Persecutory's ambition to make violent and satanic music

As with lyrics, the Turkish bands are at times brutally unambivalent in their representation of violence against Islamic symbols and persons, but it is not yet very common. The first hate-filled reference to Islam found among the fifty black metal albums gathered by Mattsson is the split record Pictavian ${ }^{15}$ Kara Metal (kara means black in Turkish) from 2011 by Turkish Godslaying Hellblast and Manzer, a French band (Fig. 3), published by French label Armée de la Mort Records. The drawn cover has a burning mosque in the background while Baphomet, ${ }^{16}$ with a pentagram around his neck, armed with a scimitar and an automatic gun, hinders anyone trying to get away, cutting the throat of a fifth victim. The cover to Hellsodomy's Masochistic Molestation (2014) has a similar image.

A particularly interesting, consciously blasphemous cover is that to Sarinvomit's CD Baphopanzers Of The Demoniacal Brigade (2015) (Fig. 4).

The image is drawn in black and white by French Chris Moyen who is a wellestablished artist in the genre of black metal covers (Chris Moyen, web). In the image, the hybrid creature, Baphopanzer - half tank, half Baphomet - destroys the Ka'ba area and kills the pilgrims. The representation has no ambition to show the area in a realistic fashion. For example, the mosque, al-masjid al-haram, surrounding the Ka'ba is not present, even as rubble. Rather, the representation is iconic, concentrating on the demolished Ka'ba, dead pilgrims, the victorious Baphopanzer creature, pentagrams, the black night sky, and a full moon (not an Islamic crescent). It seems obvious that Moyen took inspiration from Sarinvomit's song "Spreading VX Gas over Kaaba" featuring on the album. The cover uses easily recognized, established symbols in a similar fashion as the lyrics.

The covers of al-Namrood are different. Al-Namrood explores two main themes: the band's covers either allude to a regional fantasy version of history fertilized by the

\footnotetext{
15 The band Manzer is obsessed with adding "Pictavian" to their song titles and albums, deriving the word from the Pictaves, an ancient people in France.

${ }^{16}$ Baphomet is a common reference in black metal. Synonymous with Satan, his goat-human body is a wellknown symbol in popular-culture Satanism (Lewis 2001).
} 


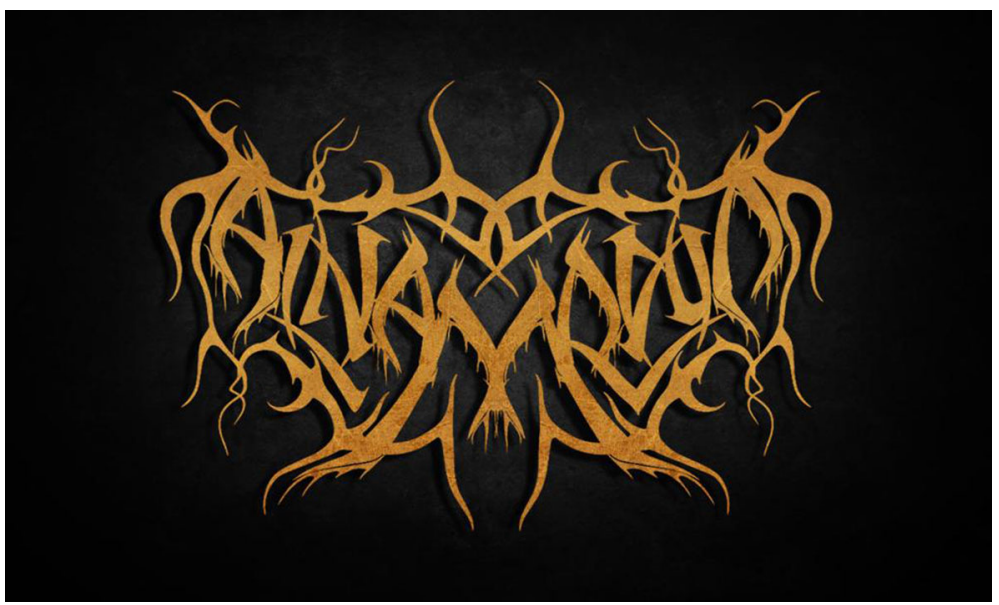

Fig. 2 al-Namrood's logo. A demonic jinn features in al-Namrood's logo stressing the opposition to religion by attaching the band to the side of the jinns. Al-Namrood recently changed its logo. The new logo, featured on the album Enkar (2017), has an anarchy symbol on the first letter and a trident on top of the A. The letters have sharper edges than the older logo. Beneath the R and the O, two saber swords cross each other. All letters are covered in cobweb

ancient civilizations of Egypt and Iraq, or portray ominous desert landscapes with crows, corpses, and mosques. In an email interview with Pastene the band wrote:

The artwork speaks a lot about the album content; we highly suggest to pay attention to the details. Megalomania is a main theme. Also we always mention something in the artwork booklet about the main plot. Our message is indirect but obvious in the same way.

The main theme, megalomania, is central to the cover to the EP Ana al Tughian (I, the tyrant, or I am the tyrant) (Fig. 5). A ruler, sitting on a spectacular throne dressed in a fantasy-like armor, flanked by two Egyptian gods, Anubis and Horus, who are holding the ankh (life) and the was-scepter (power), is viewing terrified prisoners. The pillars with undecorated capitals (and therefore not possible to identify with any specific culture) are upholding an open structure since the sky is visible behind. Or possibly this is indoors and what terrifies the prisoners is the magic of seeing the ominous sky anyway. On the floor lies a carpet or a mosaic in Roman style. The diverse features from different ancient civilizations signal royal power founded on divine authority, and translate into megalomania. The cover uses a strategy of political criticism common in repressive states and used by, not least, oppositional Islamists but also novelists in the Middle East; by writing and criticizing historical figures or made-up historical characters, the dissident is freer to express hir analysis. It is up to the reader to associate the condemnation with current political situations. ${ }^{17}$

\footnotetext{
${ }^{17}$ An example is Sayyid Qutb's use of the terms "al-jahiliyya" (time of ignorance) and "fir 'un" (Pharaoh) in his book Ma'alim fi l-tariq (Signposts) (1964) to criticize Egyptian society in general, and the president Gamal Abdel Nasser in particular, see Kepel 1985.
} 


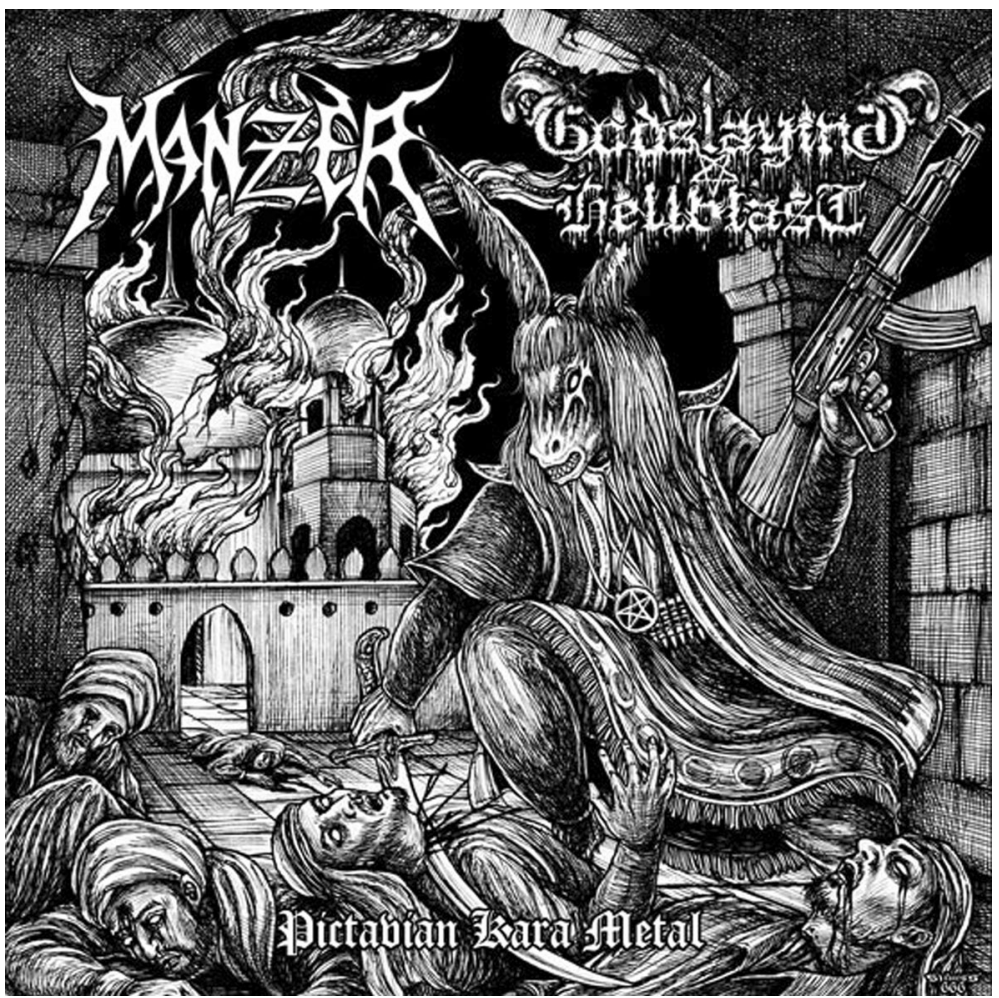

Fig. 3 Pictavian Kara Metal. Armée de la Mort Records, 2011. Artwork by Sickness 666

The second theme is found on the sleeve of the full-length album Kitab al Awthan (The book of the idols) (Fig. 6). It shows a big mosque in an empty desert below a night sky lit up by an iconic Islamic crescent. Black crows circle above the mosque. In the sand lies a corpse. Al-Namrood commented on the art in an email interview:

It articulates the dark evil that comes from these places, the [in]toxications of minds and human [...] lies and propaganda, the crows as a symbol of this darkness, and deserts [...] indicate the Arabian land.

With this cover, al-Namrood confronts Saudi Islam more directly. Being a Saudi band pointing at darkness in "the Arab land" really gives little room for interpretation, especially when put in the larger context of al-Namrood's production, repeatedly criticizing megalomaniac royalty. A similar critical edge is displayed in video clips. Contrary to the Turkish bands, al-Namrood has had video clips made to three of its songs. We do not know how much creative control al-Namrood has over the video clips but have chosen to include them anyway, particularly as the band commented on them in the interviews with Pastene.

The two first video clips, "Bat al tha ar Nar Muheja"/bata al-tha'ru nar muhija (The vengeance becomes an inner fire) and "Hayat al Khezea"/hayat al-khasi' (life of the disgraceful)", have the same overall theme. A powerful man indulges in luxurious living and un-Islamic entertainment. The connection to a desert Arab country is explicit 


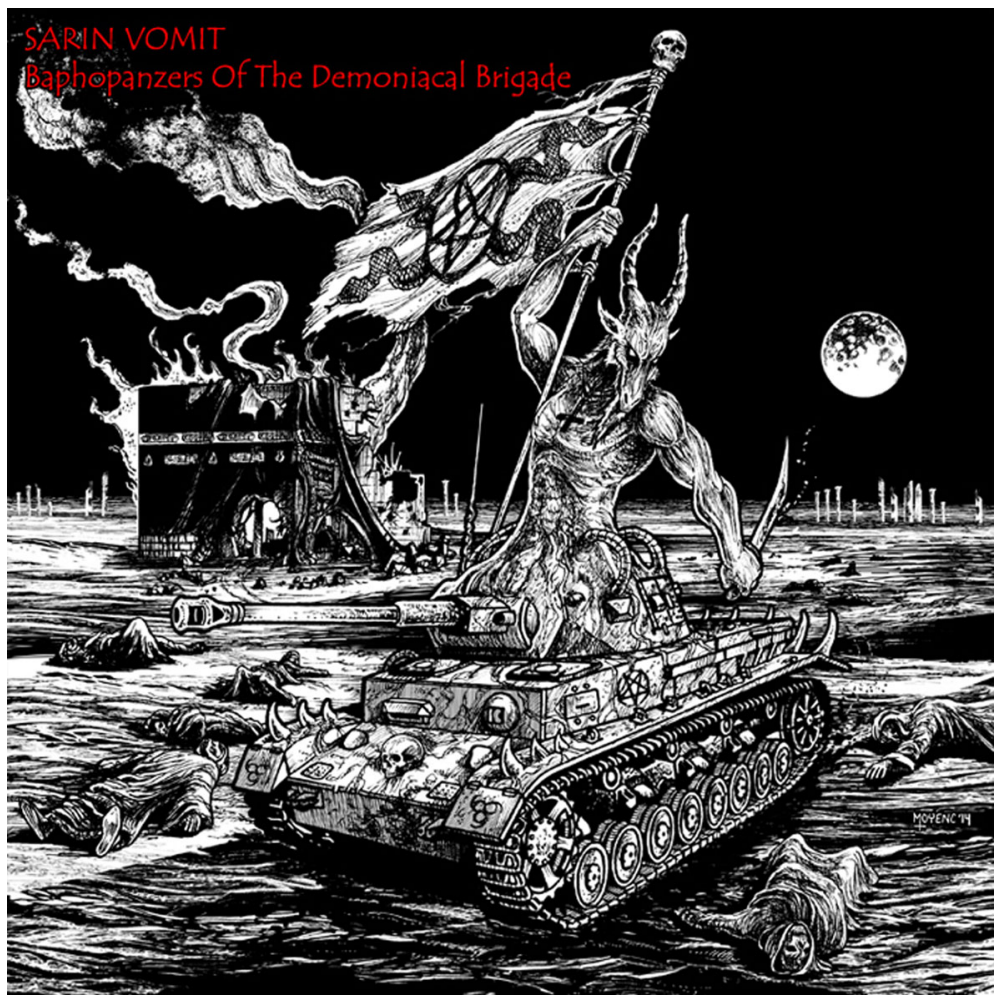

Fig. 4 Sarinvomit, Baphopanzers Of The Demoniacal Brigade. Seven Gates Of Hell, 2015. Artwork by Chris Moyen

and so is the Islamic context signaled by, among other things, men praying in a mosque, a minaret, and a whirling dervish. Both video clips make use of snakes symbolizing the ominous. In these two video clips, evil is associated with the powerful (identified as "a king" in one of Pastene's email interviews), not explicitly with Islam. Rather than pushing a black metal agenda of death and destruction, the video clips resemble political critique of the rulers for being hypocrites who spread death and destruction instead of caring for the people. The execution of a man wearing a taqiyya, a Muslim skullcap, even opens up the possibility of interpreting the video to "Hayat al Khezea" as being sympathetic of ordinary Muslims violated by oppressors who have hijacked Islam, as opposed to lyrics that rather promote the annihilation of all Muslims and Islam.

While al-Namrood has never played live, there is a tight-knit black metal scene in Turkey. At concerts, the Turkish bands are not as visually aggressive against Islam and Muslims, either on stage or on posters. That is, the explicit references to Islam and Muslims found in some of the records' artwork, are not reproduced by the bands on stage, nor are they used for advertising the shows. A certain caution is exercised even if the audience most probably approve. There are, however, visual and other markers that give away the nature of the concerts. Band logos on posters are clearly within the extreme-metal genre, coupled with pentagrams, black clothing, bullet belts, and every now and then the chanting of "hail Satan" by the audience, clarify the type of concert 


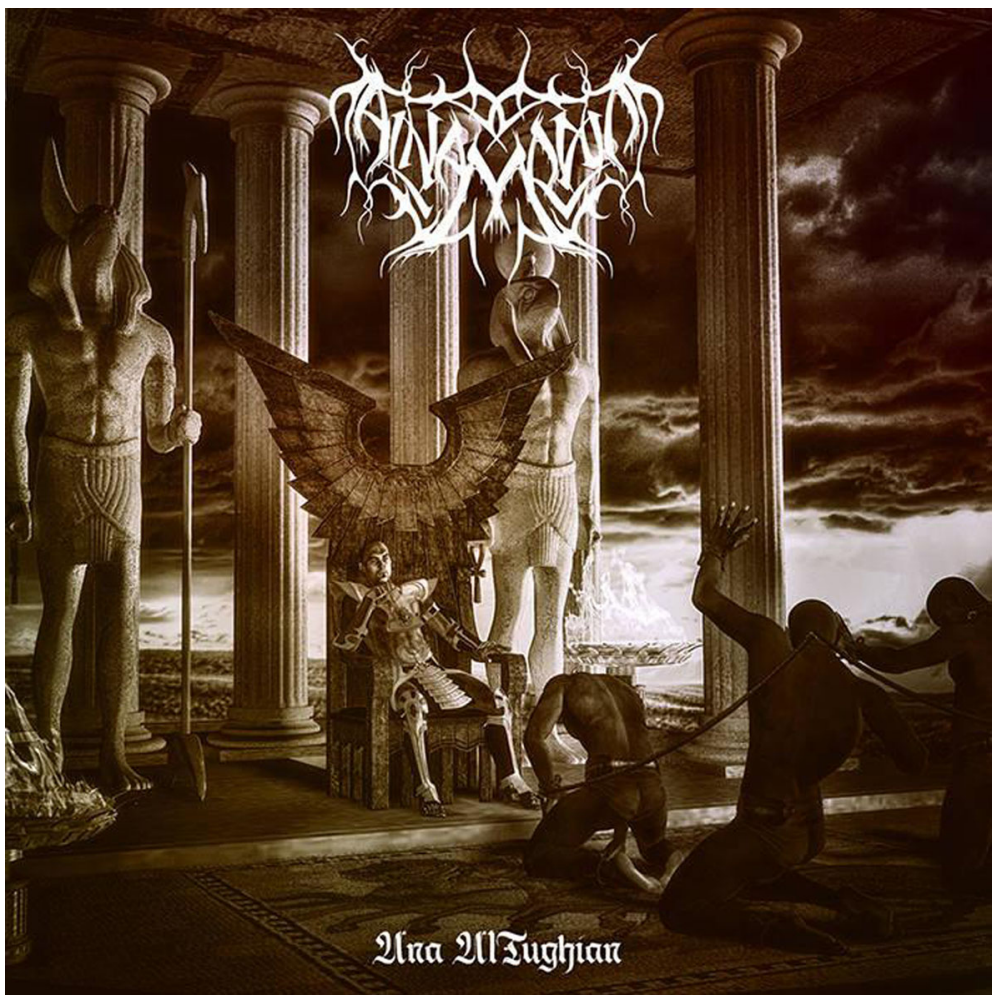

Fig. 5 al-Namrood, Ana al Tughian. Shaytan Productions, 2015. Artwork by Gragoth, Luciferium War Graphics.

one is attending. The bands are relying on the knowledge of the audience about the metanarrative of black metal to get the message across.

\section{Music and sounds}

Apart from lyrics and images, music of course primarily consists of sounds. Do these sounds try to challenge Muslim authorities in similar ways to the lyrics and images? We approach this in three ways: the inclusion of Islamic sounds (or Islamic semiotic sound resources); the violence of the soundscape of the music; and the foreignness of the soundscape.

Very few bands include samples of, for example, the call to prayer or the recitation of the Qur'an. The Turkish black metal band Zifir has used recitations of the Qur'an in the song "Ashab-I mes-eme"18 from You Must Come With Us (2007, Poem Productions) and later in "Common Insanity" from Kingdom of Nothingness (2017). In the latter case, the song features sampled snippets from Christian and Jewish recitation too. The band Ehrimen lets the call to prayer resonate over a drum break in

\footnotetext{
$\overline{18}$ The title alludes to the Qur'anic verse 90:19 where it says that those who disbelieve are "companions of the left", ashabu l-mash'amati in Arabic. 


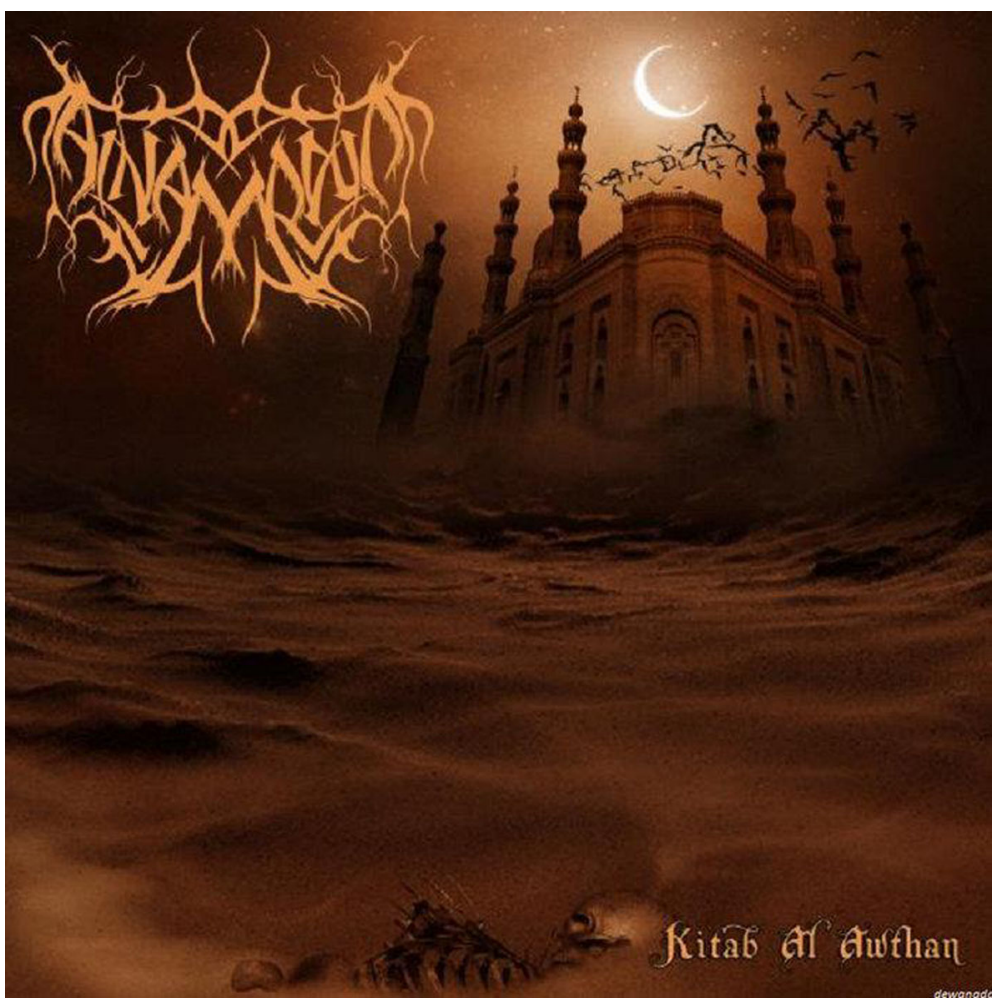

Fig. 6 al-Namrood, Kitab al Awthan. Shaytan Productions, 20,012. Artwork by Gragoth, Luciferium War Graphics.

its song "W.A.R." (2009). But generally, the bands studied refrain from that type of Islamic sounds. Though it is not common outside the Middle East, a few metal bands have included similar samples. ${ }^{19}$

The violence of the soundscape is meant to imply associations with chaos, destruction, and the demonic, a black metal hallmark. To extreme metal fans, it might be familiar but to other listeners, at first, it is probably experienced as threatening and difficult to interpret. Without presuming the reaction of an imagined audience, it is that reaction, according to interviews with black metal bands (including our own interviews), which the bands are hoping for from society at large. As has been pointed out by LeVine (2009) and Hecker (2012), this interpretation is recurrent in the Middle East. Thus, the sounds as such are likely to be experienced as anti-Islamic.

The last aspect is the foreignness of the black metal style. Once again, the black metal bands of this study are not only against Islam but also the culture of the respective societies. The Turkish bands mark their distance by not using locally developed sounds or styles. Curiously, al-Namrood's soundscape is slightly different from the Turkish

\footnotetext{
${ }^{19}$ Celtic Frost from Switzerland features the call to prayer in the intro of their song "Caress into Oblivion (Jade Serpent II)" from the album Into the Pandemonium (1987), Sanctuary Records. See also Seeds of Iblis' song "Behind the Horns of Allah from Anti Quran Rituals" (2013), Unmerciful Death Productions. The band claims to be from Iraq, but that claim has been contested.
} 
bands. At times the recordings include instruments such as qanoon, ney and semsemia giving the music a Middle Eastern flavor. But as these instruments are condemned in Saudi Wahhabi jurisprudence, using them is likely to have a double effect. It conjures up a local, Arab soundscape, and yet becomes a challenge to the religious establishment. Conservative Islamic voices are very likely to experience the music from a cultural protectionist point of view, as one of those youth-corrupting foreign elements against which local morals and culture, and specifically Islam, must protect them (Otterbeck 2004; Hecker 2012).

\section{Discussion}

When encountering recordings or live shows of black metal bands - or any other music for that matter - audiences tend to experience the whole at first, not the words, and then music or visuals or whatever other component there may be (Brackett 2000:30). Both Turkish and Saudi black metal is explicit in its subcultural nature, not conforming to sounds and forms widespread in the respective societies, and using visual and aural expressions that, when understood, challenge the societal order. The whole gives us an impression of music growling at the establishment.

Reading culture through subculture provides interesting possibilities. Why do the artists produce their art? There is a simple, recurrent answer: they hate Islam. Islam is perceived as oppressing the artists' lifestyle choices and society at large. The artists claim that Islam has always oppressed them, even when they were children, long before they knew of black metal, at school, through politics, and at home. In short, the social pressure of a dominant Islam, often portrayed as an asset by devout Muslims, is perceived as the principal obstacle to a better life. There is nothing good about God, or religion, or those following it.

The music (including lyrics, video clips, and cover art) of the bands is easily accessible on the Internet, which is a bit strange as all bands completely depend on not becoming public because it could very well lead to blasphemy charges. In conversations, the Turkish musicians repeatedly claim that since they are marginal and do not make money ("the AKP is all about the money"), they fly below the radar. By commercially distributing their music abroad, the bands might possibly get around the national legal restrictions and penal code, at least in the Turkish case, but the globalization of digital media may work against this strategy, and the state might target them if they became too publicly known (compare the case on Iranian censorship presented by Kirkegaard 2017).

Since the music studied confronts two governments and societies in which Islam is of great importance, it is a form of cultural expression that is of interest to Islamic studies. By acknowledging that Islamic semiotic resources can be used in a blasphemous way, we gain the tools to address a phenomenon rarely analyzed within the field. A multi-modal approach encourages us to pursue other empirical material than texts and interviews; we argue that this enriches our two cases. What is gained is a broader understanding of the range of different ways that people with a Muslim family background may relate to Islam, countering stereotypes of a homogeneous respect towards religion in so-called Muslim societies. A few journalists, not least Brian Whitaker (2014) have reported on atheism, and anthropologist Samuli Schielke have 
address the issue $(2012 ; 2013)$, but the social roles and positions of hate, contempt, and ridicule of Islam in such societies need to be researched thoroughly. To hate one's religion is also a relation to be taken seriously.

Open Access This article is distributed under the terms of the Creative Commons Attribution 4.0 International License (http://creativecommons.org/licenses/by/4.0/), which permits unrestricted use, distribution, and reproduction in any medium, provided you give appropriate credit to the original author(s) and the source, provide a link to the Creative Commons license, and indicate if changes were made.

\section{References}

Arnold, D. (1983). Tritone. In The new Oxford companion to music, volume 1: A-J. Oxford: Oxford University Press.

Blachére, R., \& Pattel, C. (2012). al-Mutanabbī. Encyclopaedia of Islam (2nd ed.). Leiden: Brill.

Bossius, T. (2003). Med framtiden i backspeglen. Black metal och transkulturen: Ungdomar, musik och religion i en senmodern värld. Göteborg: Diadalos.

Bossius, T. (2006). Pure fucking armageddon. In M. Leppäkari \& J. Peste (Eds.), Hotbilder: Våld, aggression och religion (pp. 15-36). Åbo: Åbo Akademi.

Brackett, D. (2000). Interpreting popular music. Berkeley: University of California Press.

Crowcroft, O. (2017). Rock in a hard place: Music and mayhem in the Middle East. London: Zed.

Doumato, E. A. (2000). Getting God's ear: Women, Islam, and healing in Saudi Arabia and the Gulf. New York: Columbia University Press.

Faxneld, P. (2017). Moskébräder och förtryck av ädla påfågelsddyrkare: Islamreception bland några typer av svenska esoteriker (Mosque arsons and oppression of noble peacock worshipers: The reception of Islam among different types of Swedish esoteric groups). Din no., 2, 88-119.

Hecker, P. (2012). Turkish metal: Music, meaning and morality in a Muslim society. Burlington: Ashgate.

Kahn-Harris, K. (2007). Extreme metal: Music and culture on the edge. Oxford: Berg.

Kepel, G. (1985). The prophet \& the pharaoh: Muslim extremism in Egypt. London: Saqi books.

Kirkegaard, A. (2017). Silencing artists: Reflections on music censorship in the case of Mahsa Vahdat. In A. Kirkegaard, H. Järviluoma, J. S. Knudsen, \& J. Otterbeck (Eds.), Researching music censorship (pp. 2851). Newcastle upon Tyne: Cambridge Scholars Publishing.

Lawton, D. A. (1993). Blasphemy. Philadelphia: University of Philadelphia Press.

LeVine, M. (2008). Heavy metal Islam: Rock, resistance, and the struggle for the soul of Islam. New York: Three Rivers Press.

LeVine, M. (2009). Doing the devil's work: Heavy metal and the threat to public order in the Muslim world. Social Compass, December, 56, 564-576.

Levine, M. (2011). How a music about death affirms life: Middle Eastern metal and the return of music's aura. In I. Peddie (Ed.), Popular music and human rights, Vol. II. London: Ashgate.

Lewis, R. J. (2001). Satanism today: An encyclopedia of religion, folklore, and popular culture. Santa Barbara: ABC-CLIO.

Mattsson, D. (2015). 'Metal is the best way for blasphemy': Islamisk representation i turkisk black metal ('Metal is the best way for blasphemy': Islamic representations in Turkish black metal). Bachelor thesis, Islamic Studies, Lund University.

Mattsson, D. (2016). Från det heliga till det vanhelgande (from the holy to the sacrilegious). Dragomanen, 18, 79-90.

Moynihan, M., \& Søderlind, D. (1998/2003). Lord of chaos: The bloody rise of the satanic metal underground (2nd ed.). New York: Feral House.

Nash, D. (2007). Blasphemy in the Christian world: A history. Oxford: Oxford University Press.

Otterbeck, J. (2004). Music as a useless activity: The logic behind conservative interpretations of music in Islam. In M. Korpe (Ed.), Shoot the singer! Music censorship today (pp. 11-16). London: Zed books.

Otterbeck, J. (2012). Wahhabi ideology of social control versus a new publicness in Saudi Arabia. Contemporary Islam, 6(3), 341-353.

Pastene, O. (2016). Black metal i Saudiarabien: Kritik mot islam och den saudiska staten (Black metal in Saudi Arabia: Criticism against Islam and the Saudi State). Bachelor thesis, Islamic Studies, Lund University.

Patterson, D. (2013). Black metal: Evolution of the cult. New York: Feral House. 
Prindle, J. D. (2014). The Devil's Prayer: Metal music in Iran. Graduate thesis: Middle East Studies, University of Utah.

Ramsey, G., \& Fatani, S. (2016). The new Saudi nationalism of the new Saudi media. In N. Mellor \& K. Rinnawi (Eds.), Political Islam and global media: The boundaries of religious identity. London \& New York: Routledge.

Schielke, S. (2012). Being a non-believer in a time of Islamic revival: Trajectories of doubt and certainty in contemporary Egypt. International Journal of Middle Eastern Studies, 44(2), 301-320.

Schielke, S. (2013). The Islamic world. In S. Bullivant \& M. Ruse (Eds.), Oxford Handbook Of Atheism. Oxford: Oxford University Press.

Sharman, J. (2017). Saudi Arabia religious chief says legalising cinemas risks 'mixing of sexes' and 'rotten' influence. Independent. http://www.independent.co.uk/news/world/middle-east/saudi-arabia-vision-2030cinema-concerts-rotten-influence-mixing-sexes-religion-islam-a7528001.html. Accessed 21 June 2017.

Venkatesh, V., Nelson, B. J., Thomas, T., et al. (2016). Exploring the language and spectacle of online hate speech in the black metal scene: Developing theoretical and methodological intersections between the social sciences and humanities. In N. Varas-Diaz \& N. Scott (Eds.), Heavy metal music and the communal experience (pp. 127-150). Lanham: Lexington Books.

Whitaker, Brian (2014). Arabs Without God. 2nd Edn. publ. 2017). Self-published through CreateSpace.

\section{Web}

Al-Hayat: (Article from January 28, 2008). http://www.daralhayat.com/archivearticle/183130. Not available online anymore. Accessed 29 January 2012.

al-Namrood: http://www.alnamrood.com/. Accessed 21 June 2017.

Arab News: http://www.arabnews.com/node/1257201/saudi-arabia. Accessed 24 March 2018.

Chris Moyen: http://www.chrismoyen.com. Accessed 21 June 2017.

Encyclopaedia Metallum: http://www.metal-archives.com/lists/SA. Accessed 23 Nov. 2016.

Freedomehouse: https://freedomhouse.org/report/freedom-net/2016/saudi-arabia. Accessed 23 Nov. 2016.

Filhakikat: http://filhakikat.net/al-namrood-mizantropinin-isyan-yuzu/. Accessed 21 June 2017.

Human Rights First: http://www.humanrightsfirst.org/sites/default/files/Compendium-Blasphemy-Laws.pdf. Accessed 21 June 2017.

Legislation online: http://legislationline.org/documents/action/popup/id/6872/preview. Accessed 19 June 2017.

Sarinvomit: https://sarinvomit.bandcamp.com/album/baphopanzers-of-the-demoniacal-brigade-2. Accessed 4 May 2017.

\section{Music}

Darkthrone (1993). Under A Funeral Moon. Peaceville Records.

Ehrimen (2009). W.A.R. Independently Released Promo Single.

Godslaying Hellblast (2011). Pictavian Kara Metal. Armée de la Morte Records.

Hellsodomy (2014). Masochistic Molestation. Dead Bangers Records.

Horrocious (2015). Obscure Dominance of Nothingness. The Horror Dimension.

Impuration (2012). Sanctities We Raped. Gravplass Production.

Al-Namrood (2009). Astfhl Al Tha'r. Shaytan Productions.

Al-Namrood (2012). Kitab Al Awthan. Shaytan Productions.

Al-Namrood (2015). Ana Al Tughian. Shaytan Productions.

Persecutory (2016). Perversion Feeds Our Force. Hell's Hammer Music.

Sarinvomit (2015). Baphopanzer of the Demonical Brigade. Seven Gates of Hell Records.

Zifir (2007). You Must Come With Us. Poem Productions.

Zifir (2017). Kingdom of Nothingness. Duplicate Records. 